\title{
Ellis-van Creveld syndrome: report of 15 cases in an inbred kindred
}

\author{
ELIAS OLIVEIRA DA SILVA*†, DENISE JANOVITZ, $\dagger$ AND \\ SÍLVIO CAVALCANTI DE ALBUQUERQUE†
}

From the *Departmento de Biologia Geral, Seç̧ão de Genética, Universidade Federal de Pernambuco, and $\nmid$ Instituto Materno-Infantil de Pernambuco (IMIP), Recife, Brazil

SUMMARY An inbred kindred with 15 cases of the autosomal recessive Ellis-van Creveld syndrome is reported. The ages of the 12 living affected varied between 3 and 82 years. The main characteristics include polydactyly of the hands and feet and several other skeletal anomalies, oral manifestations, and malformations of the heart in $50 \%$ of the living affected.

The first case of Ellis-van Creveld syndrome (chondroectodermal dysplasia) was reported by McIntosh in $1933,{ }^{1}$ but only in 1940 was it defined as a syndrome by Ellis and van Creveld. ${ }^{2}$ Typically the syndrome is characterised by dwarfism, polydactyly, hypoplastic nails, oral manifestations, and malformations of the heart in about $50 \%$ of cases. ${ }^{3-5}$ Inheritance is autosomal recessive.

We report 15 cases of Ellis-van Creveld syndrome in an inbred kindred resident in a farm called 'Cavalo', Buíque Count, PE, Brazil. The number of living affected was 12 and their ages varied between 3 and 82 years. There were no neonatal deaths in this kindred. The first Brazilian cases were reported by Waldrigues et al. ${ }^{6}$

\section{Methods}

All living affected were examined and radiological, cardiac, and odontological studies were performed. Routine laboratory examinations were also performed and six patients were karyotyped. Dermatoglyphic studies (TRC values and $a-b$ ridge counts) were performed in ten patients (four men and six women). To compare the mean values of TRC and $a-b$ ridge counts of the affected persons with the mean values observed in Brazilian populations, we used the data of Toledo et al ${ }^{7}$ and Beiguelman. ${ }^{8}$ The statistical method applied to the analysis of the data was Student's $t$ test.

During the collection of the genealogical data, information about persons who could not be examined was checked separately through several members of the family.

Received for publication 10 December 1979

\section{Results}

\section{GENETICS}

Fig 1 shows the pedigree of the family with 15 cases of Ellis-van Creveld syndrome. A total of 86 members of the family, including all living affected, was examined. The majority of the affected persons had unaffected parents. Patients V.188, V.189, V.190, V.193, and V.197 were children of an affected man and, as inheritance is recessive, it is presumed that the mother (a second cousin of the husband) was a heterozygote. Note that the nine children of the first marriage of this man (with an unrelated woman) were all normal. Clinical examination and $x$-rays of the hands of some subjects, presumably heterozygotes, did not show any peculiarity that might suggest a heterozygous effect of the gene.

\section{ANTHROPOMETRIC DATA}

The heights of the four adult patients were 142,149 , 158.5 , and $161 \mathrm{~cm}$, and their respective ages were $82,66,73$, and 61 years. The last two heights can be considered normal, at least for rural populations from the north-east of Brazil. Also normal were the heights of patients V.188 $(154 \mathrm{~cm})$, V.189 $(152 \mathrm{~cm})$, V.197 $(95 \mathrm{~cm})$, VI.31 $(126 \mathrm{~cm})$, and VI. $32(115 \cdot 5 \mathrm{~cm})$, whose respective ages were $15,14,3,9$, and 7 years. The other three affected children, belonging to the same sibship, had heights well below the lower limit of normal ${ }^{9}$ : V.111, 10 years old, $101 \mathrm{~cm}$; V.113, 7 years, $100 \mathrm{~cm}$, and V.115, 4 years, $84 \mathrm{~cm}$. Only these last patients, together with subject III.1 had acromelic micromelia. The hand measurements of the other affected persons were normal. No 


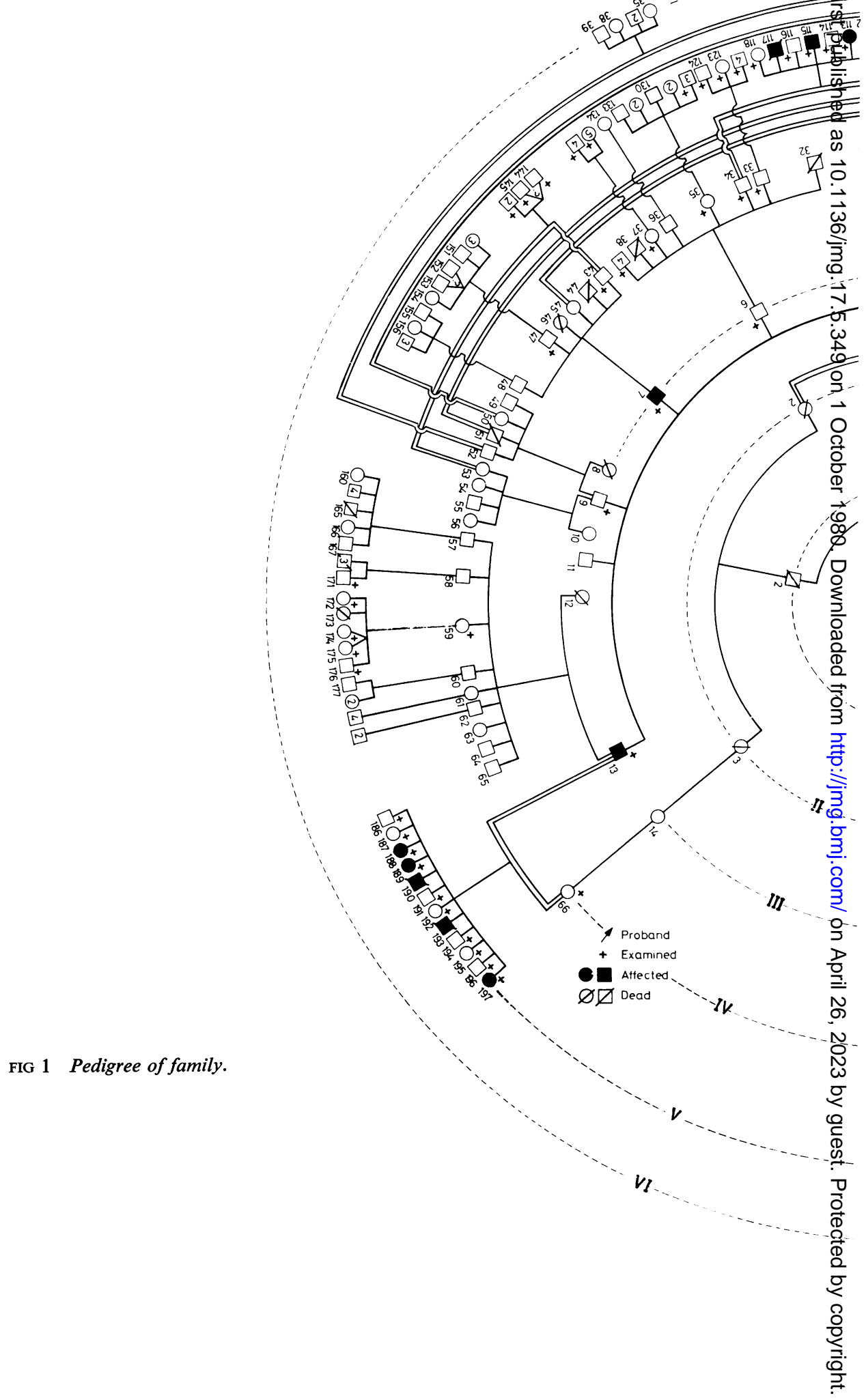


disproportion was observed between upper arm and forearm. Ocular measurements showed that the majority of the patients had mild hypertelorism.

\section{CLINICAL AND RADIOLOGICAL FINDINGS}

The main clinical and radiological findings are listed in table 1 and illustrated in figs $2,3,4$, and 5 . According to Temtamy and McKusick, ${ }^{10}$ postaxial polydactyly A consists of a well-formed articulated extra digit at the ulnar or fibular edge and preaxial polydactyly 1 is polydactyly of a thumb or big toe or both. All our patients except one had postaxial polydactyly $A$ in the four extremities. The proband had preaxial polydactyly 1 in the right lower extremity and postaxial $\mathrm{A}$ in the others. A variety of other clinical and radiological signs, not included in table 1, were observed in at least one patient: strabismus, cryptorchidism, retarded skele- tal maturation, cubitus valgus, hypoplastic cubitusp supernumerary carpal bone centre, fusion of lunate and triquetral bones, deformity of the hamate hypoplastic 4th metacarpal bone, metacarpophas langeal subluxation (5th and 6th fingers), supers numerary fingers without associated metacarpals clinodactyly of the 2nd, 4th, and 6th fingers, hypo plastic phalanges, conical phalanges, ankylosis of finger joints, coxa valga, disturbance in bone modelling of the tibial metaphysis, club foot, large cuboid, large sesamoids at distal extremity of the 1sti metatarsal, long 3rd metatarsal, wide gap betweef 1st and 2nd toes, metatarsophalangeal subluxatio of 5th toe, short 3rd toe, long 4th toe, and ovete riding of the $3 \mathrm{rd}$ and 6 th toes.

CARDIAC FINDINGS

Cardiological evaluation performed in all living

TABLE 1 Main clinical and radiological findings in 12 patients with Ellis-van Creveld syndrome

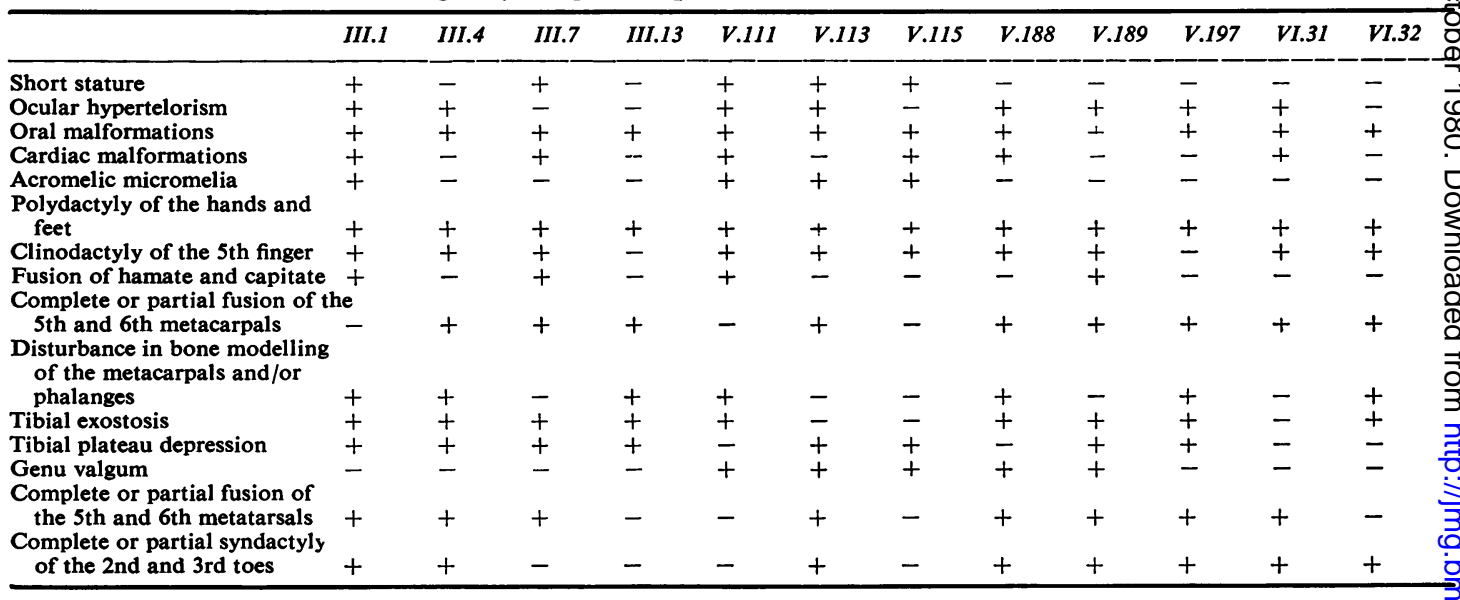

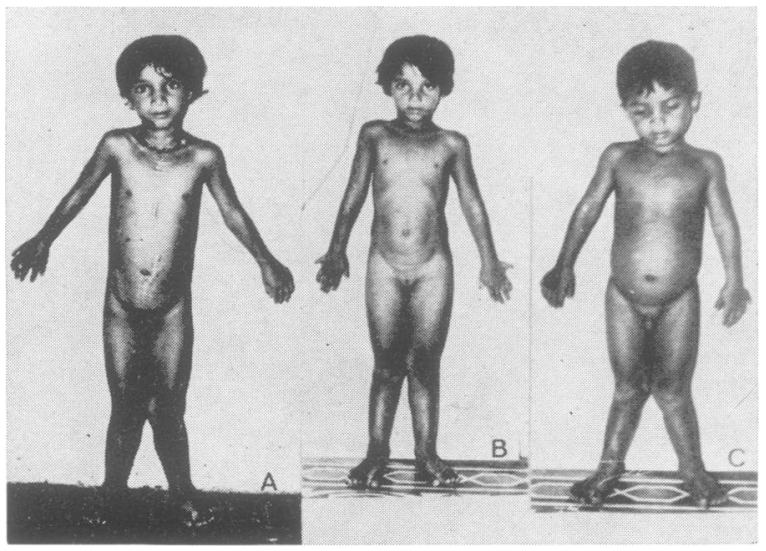

FIG $2 A$-C Three sibs with Ellis-van Creveld syndrome? Note the presence of mild ocular hypertelorism, genu N valgum, and polydactyly of the hands and feet. A. Girln of 10 years, $101 \mathrm{~cm}$ in height. (Scars on the abdomen and thorax from previous surgery on the large intestine and construction of atrial septum and correction of mitral cleft.) B. Girl of 7 years, $100 \mathrm{~cm}$ in height. C. Boy of 4 years, $84 \mathrm{~cm}$ in height. 


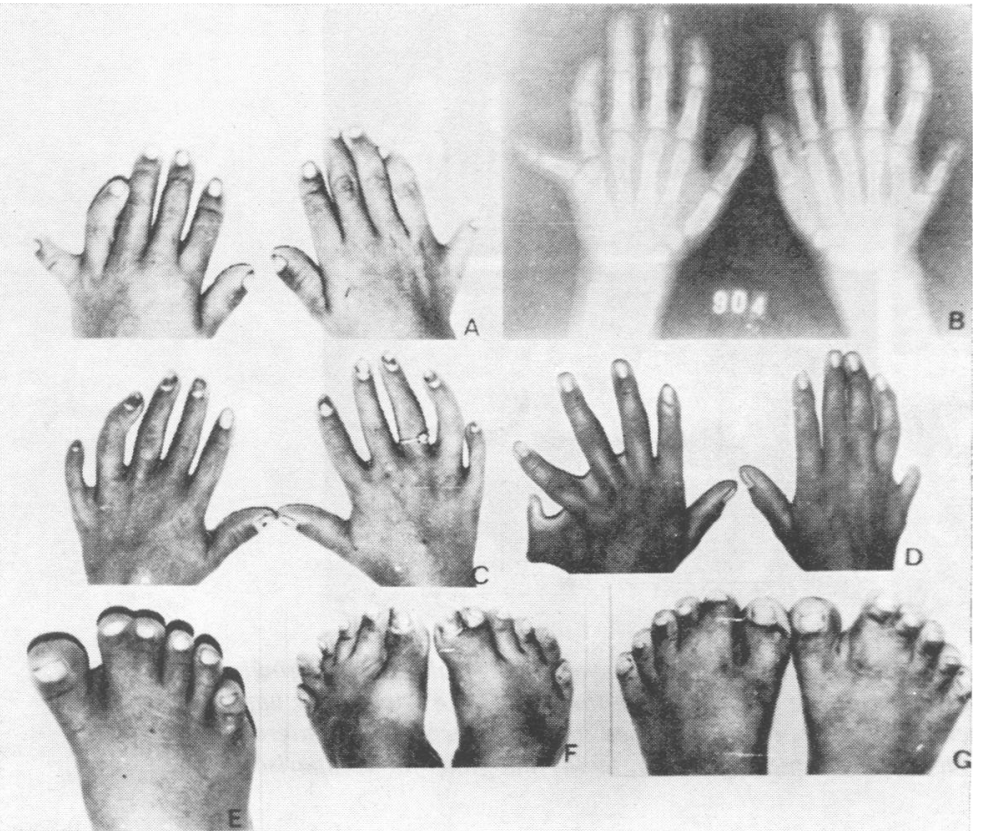

FIG 3 A-G. Polydactyly of the hands and feet in persons with Ellis-van Creveld syndrome. $A$ and $B$. Hands of the same patient showing clinodactyly of the 5th fingers, abnormal position of the left 6 th finger, disturbance in bone modelling of the phalanges, complete fusion of the 5th and 6th metacarpals, and supernumerary carpal bone centre. (The patient was a girl of 7 years.) C. Clinodactyly of the 5th and 6th fingers. D. Clinodactyly of the 5th finger on the right hand and deformity of the 6th finger on the left hand. $E$. Wide gap between 1st and 2nd toes, and complete syndactyly of the 2nd and 3rd toes. F. Club foot. (Note the duplication of the hallux on the right foot.) G. Wide gap between $1 \mathrm{~s}$ and 2nd toes on the right foot and bilateral partial syndactyly of the 2nd and $3 r$ toes. Note that the nails are essentially normal in all cases.
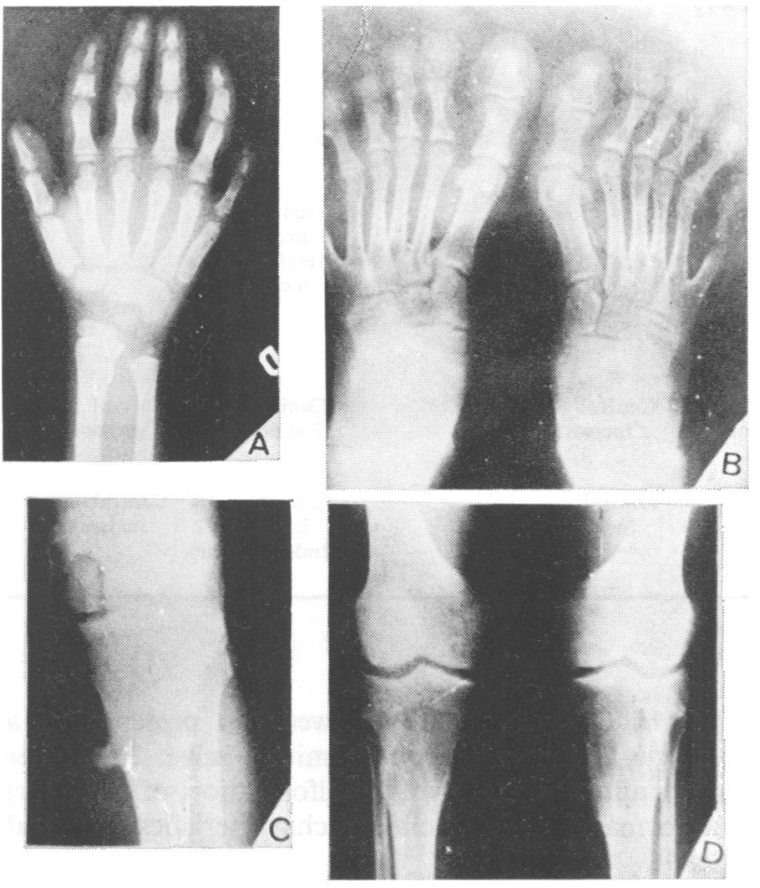

FIG $4 A$-D. $X$-rays of right hand, feet, and segments of lower limbs of 4 patients with Ellis-van Creveld syndrome. A. Polydactyly, clinodactyly of the 5th and 6th fingers, disturbance in bone modelling of the phalanges, hamate fused with capitate, and short distal cubitus. B. Polydactyly and partial bilateral fusion of 5th and 6th metatarsals. C. Tibial plateau depression and tibial exostosis (left leg). D. Bilateral tibial plateau depression, disturbance in bone modelling of the tibial metaphysis and tibial exostosis. 

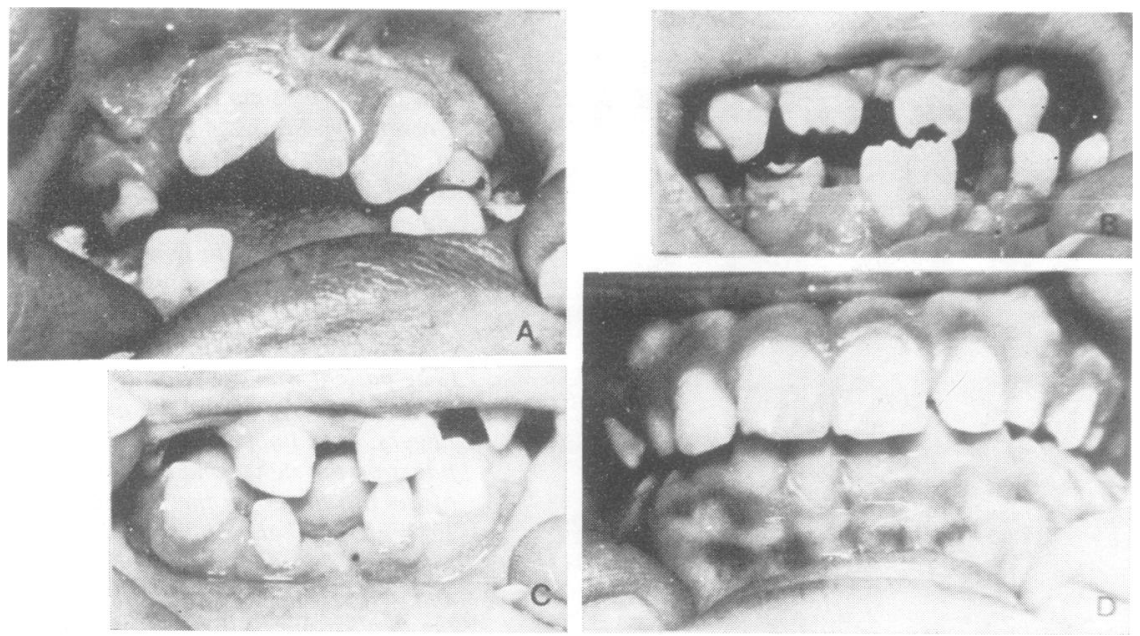

FIG 5 A-C. Oral malformations in 3 pateints with Ellis-van Creveld syndrome. Malocclusion, gingival hypertrophy, labiogingival adherences, diastema, and hypodontia are present in the three cases. A. Accessory upper labiogingival frenulum, torsiversion of the maxillary central incisors, and transposed maxillary central and lateral left incisors. B. Serrated incisal margins. C. Conical teeth. D. Normal occlusion, teeth, and gums for comparison.

TABLE 2 Oral malformations in 7 patients with Ellis-van Creveld syndrome

\begin{tabular}{|c|c|c|c|c|c|c|c|}
\hline & $V .111$ & $V .113$ & $V .115$ & $V .188$ & $V .189$ & $V I .3 I$ & $V I .32$ \\
\hline Malocclusion & + & + & + & -- & + & - & - \\
\hline Labiogingival adherences & + & - & + & - & + & - & + \\
\hline $\begin{array}{l}\text { Gingival hypertrophy } \\
\text { Labiogingival frenulum }\end{array}$ & + & + & + & -- & - & + & + \\
\hline $\begin{array}{l}\text { hypertrophy } \\
\text { Accessory labiogingival }\end{array}$ & + & + & + & + & $\div$ & + & + \\
\hline frenula & + & + & - & - & + & - & - \\
\hline Serrated incisal margins & + & - & + & - & + & - & - \\
\hline Torsiversion & + & - & - & + & - & + & + \\
\hline Transposition & + & - & - & + & - & - & - \\
\hline Diastema & + & + & + & + & + & + & + \\
\hline $\begin{array}{l}\text { Conical teeth } \\
\text { Enamel hypoplasia }\end{array}$ & + & - & - & - & -- & + & + \\
\hline Maxilla & 1st molars $(P)$ & $\begin{array}{l}\text { All incisors } \\
\text { (P) }\end{array}$ & $\begin{array}{l}\text { Right 1st molar } \\
\text { (P) }\end{array}$ & & & $\begin{array}{l}\text { Right central } \\
\text { incisor }(P) \\
\text { Left lateral } \\
\text { incisor }(P)\end{array}$ & \\
\hline Mandible & 1st molars $(\mathrm{P})$ & $\begin{array}{l}\text { 1st molars (P), } \\
\text { right 2nd } \\
\text { molar (D) }\end{array}$ & $\begin{array}{l}\text { Left 1st molar } \\
\text { (P) }\end{array}$ & & & & $\begin{array}{l}\text { Right 1st molar } \\
\text { (P) }\end{array}$ \\
\hline $\begin{array}{l}\text { Congenital absence of teeth } \\
\text { Maxilla }\end{array}$ & $\begin{array}{l}\text { Right lateral } \\
\text { incisor (P) } \\
\text { Canines (D) } \\
\text { 2nd molars (D) }\end{array}$ & & $\begin{array}{l}\text { Lateral } \\
\quad \text { incisors (D) }\end{array}$ & $\begin{array}{l}\text { Central } \\
\text { incisors (P) }\end{array}$ & & $\begin{array}{l}\text { Canines }(\mathrm{P}) \\
\text { 2nd premolars }\end{array}$ & $\begin{array}{l}\text { Lateral } \\
\quad \text { incisors (P) }\end{array}$ \\
\hline Mandible & $\begin{array}{l}\text { Central } \\
\text { incisors (P) } \\
\text { 1st molars (D) } \\
\text { 2nd molars (D) }\end{array}$ & $\begin{array}{l}\text { Central } \\
\text { incisors (P) }\end{array}$ & $\begin{array}{l}\text { Lateral } \\
\text { incisors (D) }\end{array}$ & $\begin{array}{l}\text { Central } \\
\text { incisors (P) }\end{array}$ & & $\begin{array}{l}\text { Lateral } \\
\text { incisors (P) } \\
\text { 2nd premolars }\end{array}$ & $\begin{array}{l}\text { Central } \\
\text { incisors (P) }\end{array}$ \\
\hline
\end{tabular}

D, deciduous; $P$, permanent.

affected, which included thoracic $x$-rays, cardiac auscultation, and electrocardiogram showed anomalies in six patients consistent with atrial septal defect. Their ages were $82,66,15,10,9$, and 4 years. Haemodynamic studies, performed only in case
V.111 (10 years old), showed the presence of a single atrium with a cleft mitral valve. The other 7 two adult patients with malformation of the heart $\overline{0}$ also manifested the clinical characteristics of mitral cleft. 
TABLE 3 TRC values and $a-b$ counts observed in 10 patients (4 males and 6 females) with Ellis-van Creveld syndrome

\begin{tabular}{llllll}
\hline & $T R C$ & & \multicolumn{2}{l}{$a-b$ counts } \\
\cline { 2 - 3 } \cline { 5 - 5 } \cline { 5 - 5 } & Male & Female & & Male & Female \\
\hline & 260 & 161 & 75 & 60 \\
& 257 & 314 & 82 & 73 \\
& 422 & 382 & 77 & 78 \\
& 393 & 338 & 71 & 87 \\
& & 296 & & 57 \\
& & 387 & & 70 \\
\hline Total & 1332 & 1878 & 305 & 425 \\
$\overline{\mathbf{x}}$ & 333 & 313 & $76 \cdot 25$ & $70 \cdot 83$ \\
SD & $75 \cdot 21$ & $75 \cdot 56$ & $3 \cdot 96$ & $10 \cdot 22$ \\
\hline
\end{tabular}

ORAL MANIFESTATIONS

Excluded from the odontological studies were all adult patients who had already had almost all their teeth extracted, and the youngest affected child who made great resistance to the examination. Table 2 shows the oral manifestations which include malocclusion, labiogingival adherences, gingival hypertrophy, labiogingival frenulum hypertrophy, accessory labiogingival frenula, serrated incisal margins, torsiversion, dental transposition, diastema, conical teeth, enamel hypoplasia, and hypodontia.

\section{LABORATORY ST UDIES}

Laboratory examinations were all normal and included total blood counts and the following serum levels: glucose, urea, creatinine, cholesterol, calcium, phosphorus, sodium, potassium, $\mathrm{CO}_{2}$, and alkaline phosphatase. Karyotype was performed in six patients and no chromosome abnormalities were detected.

\section{DERMATOGLYPHIC STUDIES}

TRC values and $a-b$ counts in ten patients are shown in table 3. Comparing the mean values of TRC and $a-b$ counts observed in these patients with normal parameters for both sexes, according to data obtained from Brazilian populations, there was a statistically significant increase of these values as demonstrated by Student's $t$ test: TRC: $t$ (male) $=$ $46 \cdot 12$ and $t$ (female) $=50 \cdot 06$. At a significance level of 0.01 the theoretical $t$ is 1.98 with 104 and 108 degrees of freedom for males and females, respectively; $a-b$ counts: $t$ (male) $=3.72$ and $t$ (female) $=9 \cdot 74$. At a significance level of 0.01 , $t$ (theoretical) $=2 \cdot 70$, with 40 and 42 degrees of freedom for males and females, respectively.

\section{Discussion}

Because of the lack of reliable information about more remote antecedents, it is difficult to establish the origin of the abnormal recessive gene in this small inbred population, but it is possible that it was introduced by one of the parents of the sibs I.1 and I. 2 who were probably heterozygotes. McKusick et al $^{11}$ made a complete study of Ellis-van Creveld syndrome in the Amish population of Pennsylvania, USA (52 cases) and explained the high frequency of the gene based on the founder principle.

In this series, all the affected persons had polydactyly of the hands and feet. Although polydactyly of the hands invariably occurs, polydactyly of the feet is present only in about $10 \%$ of the patients with Ellis-van Creveld syndrome. ${ }^{12}$ An anomaly found in most reported cases is nail hypoplasia, but the nails of our patients were essentially normal and this has also been observed by other authors. ${ }^{11} 1314$

Among the living affected the frequency of cardiac malformation was exactly $50 \%$ (six patients), which agrees well with observations made by several authors. $^{3-5}$ On the other hand, we did not get reliable information about the cause of death of the other three affected persons and this would be of interest because malformation of the heart appears to be the main determinant of longevity..$^{15} \mathrm{It}$ is noteworthy that one of these six patients was a woman of 82 years of age (the oldest member of the family), who, despite having cardiac problems, never complained of any symptom related to the cardiovascular system. The presence of a single atrium observed in our only patient who underwent haemodynamic studies is not surprising because a single atrium is found in $40 \%$ of all cardiac anomalies in the syndrome. ${ }^{17}$ Mitchell and Waddell ${ }^{18}$ suggest that the designation 'chondroectodermal dysplasia' is inadequate because it does not denote mesodermal involvement and propose that a more appropriate designation would be 'ectomesodermal dysplasia'.

The most important oral manifestations of Ellisvan Creveld syndrome are labiogingival adherences, accessory frenula, and hypodontia. These findings are present in the majority of published cases. The most frequent manifestation in our series was hypodontia and only one patient had all his teeth. The cases presented by Goor et al $^{\mathbf{1 4}}$ did not have hypodontia and their teeth were normal.

Laboratory studies, including chromosome analysis, appear to be of no diagnostic value. Six patients were karyotyped, but no chromosome abnormality was detected. Affected persons with normal karyotypes have been described by many authors. ${ }^{19-21}$

Dermatoglyphic studies performed in ten cases showed a statistically significant increase of TRC and $a-b$ counts. The high values of TRC can be 
explained by the high incidence of whorls observed in these patients: 87 whorls in a total of 117 fingers (one of the patients had had three fingers of a hand amputated). Frias and Cascos ${ }^{21}$ analysed the dermatoglyphs of three patients with Ellis-van Creveld syndrome and also found an excess of whorls: $20 / 32$.

Our special thanks to Dr Fernanda Wanderley for the cardiological evaluation of most patients. We are also grateful to the following: Professor Aluizio B Coutinho, for critically reading the manuscript; Dr Artur Neto for his help in the odontological examination; Dr Bento Bezerra for the cardiological examination of one patient; Dr Eufrásio Santos for statistical assistance; Miss Eunice Sumi for helping in the bibliographical research; $\mathrm{Mr}$ Blesman Modesto (Mayor of Buíque, PE) for facilitating our access to the farm where the family described in this work resides; and Miss Mary Beaubrun for correcting the English.

\section{References}

1 McIntosh R. In: Holt LE, Howland J, eds. Diseases of infancy and childhood. 10th ed. New York: AppletonCentury-Crofts, 1933:362.

2 Ellis RWB, van Creveld S. A syndrome characterized by ectodermal dysplasia, polydactyly, chondrodysplasia, and congenital morbus cordis. Report of 3 cases. Arch Dis Child 1940;15:65-84.

s Tubbs FE, Crevasse L, Green JR Jr. Congenital heart disease in an adult with the Ellis-van Creveld syndrome. Ann Intern Med 1962;57:829-34.

- Moore TC. Chondroectodermal dysplasia (Ellis-van Creveld syndrome) with bronchial malformation and neonatal tension lobar emphysema. $J$ Thorac Cardiovasc Surg 1963;46:1-10.

5 Milgram JW, Bailey JA. Orthopaedic aspects of the Ellis-van Creveld syndrome. Bull Hosp Joint Dis 1975; 36:11-9.

- Waldrigues A, Grohmann LC, Takahashi T, Reis HMP. Ellis-van Creveld syndrome. An inbred kindred with five cases. Rev Bras Pesqui Med Biol 1977;10:193-8.
7 Toledo SPA, Saldanha SG, Laurenti R, Saldanha PH Dermatoglifos digitais e palmares de indivíduos normais: da população de São Paulo. Rev Paul Med 1969;75:1-10 $\overrightarrow{\overline{\bar{N}}}$

8 Beiguelman B. Genetics of a-b and A'-d ridge counts $?$ Rev Bras Pesqui Med Biol 1971 ;4:337-42.

- Marcondes E, Berquó ES, Luongo J, et al. Estudo antropo-文 métrico de crianças brasileiras de zero a doze anos de idade. An Nestlé 1970;84:75.

10 Temtamy S, McKusick VA. Synopsis of hand malformations with particular emphasis on genetic factors. Birtho Defects 1966;5:125-84.

11 McKusick VA, Egeland JA, Eldridge R, Krusen DE. $\overrightarrow{0}$ Dwarfism in the Amish. I. The Ellis-van Creveld syndrome.Johns Hopkins Med J 1964;115:306-36.

12 Bailey JA. Disproportionate short stature. Philadelphia:ब Saunders, 1973:198-213.

13 Behar A, Rachmilewitz E. Ellis-van Creveld syndromę̧ Report of one case associated with abiotrophy of elastictissue in the cardiovascular system. Arch Intern Med or 1964;113:606-11.

14 Goor D, Rotem Y, Friedman A, Neufeld HN. Ellis-van Creveld syndrome in identical twins. Br Heart $J 1965 ; 0$ 27:797-804.

15 Giknis FL. Single atrium and the Ellis-van Creveld syndrome. J Pediatr 1963;62:558-64.

16 McKusick VA. A genetic view of cardiovascular disease. The Lewis A Conner Memorial Lecture. Circulation $1964 ; 30: 326-57$

17 Franz C, Mennicken H, Butzler HO, Henscher L. $\stackrel{\mathbb{D}}{?}$ Angeborene herzfehler beim Ellis-van Creveld-syndrom. $\vec{\omega}$ Literaturanalyse und bericht uber eine eigene beobachtung. $Z$ Kinderheilk 1974;117:127-44.

18 Mitchell FN, Waddell WW Jr. Ellis-van Creveld syn-D drome. Report of two cases in siblings. Acta Paediatr 1958;47:142-51.

10 Patriarca PL, Lambertenghi IV, Ninatti GP. La síndromeō di Ellis-van Creveld. Contributo casistico e studio cito-ِ̋ genetico. Minerva Med 1968;59:243-53.

20 Laporte MMG, David-Chaussé J. Sur un cas de syndrome d'Ellis-van Creveld chez un homme de 61 ans. Bordeaux $\overline{\underline{O}}$ Med 1971;4:175-90.

21 Frias MLM, Cascos AS. Síndrome de Ellis-van Creveld. Rev Clin Esp 1974;133:311-8.

Requests for reprints to Dr Elias Oliveira da Silva, Departamento de Biologia Geral, Secção de 3 Genética, Universidade Federal de Pernambuco, Cidade Universitária, 50000 Recife, PE, Brazil. 